\title{
The phytochemical lindleyin, isolated from Rhei rhizoma, mediates hormonal effects through estrogen receptors
}

\author{
T Usui $^{1}$, Y Ikeda ${ }^{1,2}$, T Tagami ${ }^{1}$, K Matsuda $^{1}$, K Moriyama $^{1}$, \\ K Yamada ${ }^{1}$, H Kuzuya ${ }^{1}$, S Kohno ${ }^{2}$ and A Shimatsu ${ }^{1}$ \\ ${ }^{1}$ Clinical Research Institute, Center for Endocrine and Metabolic Disease, Kyoto National Hospital, Kyoto, Japan \\ ${ }^{2}$ Department of Pharmacology, Kyoto Pharmaceutical University, Kyoto, Japan \\ (Requests for offprints should be addressed to T Usui, 1-1 Mukaihata-cho Fukakusa, Fushimi-ku Kyoto, 612-8555 Japan; Email: tusui@kyotolan.hosp.go.jp)
}

\begin{abstract}
Some plant compounds or herb mixtures are popular alternatives to conventional therapies and contain organic compounds that bind to some nuclear receptors, such as the estrogen receptor (ER), to exert various biological effects. We studied the effect of various herbal extracts on $\mathrm{ER} \alpha$ and $\mathrm{ER} \beta$ isoforms. One herbal extract, Rhei rhizoma (rhubarb), acts as an agonist to both $\operatorname{ER} \alpha$ and $\operatorname{ER} \beta$. The phytochemical lindleyin, a major component of rhubarb, might contribute to this estrogenic activity through ER $\alpha$ and ER $\beta$. 4-Hydroxytamoxifen, an ER antagonist, completely reversed the estrogenic activity of lindleyin.
\end{abstract}

Lindleyin binds to ER $\alpha$ in vitro, as demonstrated using a fluorescent polarization assay. The in vivo effect of rhubarb extract was studied using a vitellogenin assay system in the freshwater fish, Japanese medaka (Oryzias latipes). There were marked increases in serum vitellogenin levels in male medaka exposed to rhubarb extract. We conclude that lindleyin, a component of some herbal medicines, is a novel phytoestrogen and might trigger many of the biological responses evoked by the physiological estrogens. Journal of Endocrinology (2002) 175, 289-296

\section{Introduction}

Phytoestrogens are plant (predominantly legumes and grasses) substances that have structural and functional similarity to estradiol-17 $\beta$ (Jordan et al. 1985). Plantderived isoflavonoids, coumestans, and ligands compete with estradiol with varying affinities to bind to estrogen receptors (ERs), induce transcription of estrogenresponsive genes (Kuiper et al. 1998) and, depending on the outcome measured, either mimic or antagonize the action of steroidal estrogens (Hughes 1996). Humans are exposed to phytoestrogens through their diet, a major source being soy and soy-derived foods, which contain high levels of the isoflavone class of non-steroidal estrogenic compounds, genistein and daidzein (Martin et al. 1978, Price \& Fenwick 1985, Setchell \& Cassidy 1999, de Kleijn et al. 2001). The impact of dietary phytoestrogens on normal biological processes was first recognized in sheep (Schinckel 1948). Observations on sheep grazing on fields rich in clover and cheetahs fed high soy diets in zoos suggested that flavonoids and related phytochemicals can affect mammalian health (Bennetts et al. 1946, Shutt 1976, Setchell et al. 1987). Therefore, the fact that these compounds function as phytoestrogens might be an important dietary factor affecting human health (Adlercreutz 1995, Bingham et al. 1998, Cline \& Hughes 1998, Humfrey 1998, Murkies et al. 1998, Tham et al. 1998). Among their widespread clinical effects, dietary phytoestrogens are purported to reduce the risk of cancer, have antioxidant and free radical scavenger activity, reduce serum cholesterol, induce cellular differentiation, and inhibit angiogenesis (Fotsis et al. 1993, Murkies et al. 1998, Tham et al. 1998). Phytoestrogens can therefore potentially benefit humans, and yet there are probably many more unidentified phytoestrogens in nature.

Herbal therapies are unconventional treatments in wide use for many diseases. They can have important biological activity. For example, saw palmetto inhibits $5 \alpha$-reductase, an enzyme involved in testosterone metabolism (Delos et al. 1995), and St Johnswort, similar to pharmacologic antidepressants, blocks monoamine oxidase activity (Cott 1997). Recently, DiPaola et al. (1998) reported that PC-SPES (Botaniclab, Byea, CA, USA), a commercially available combination of eight herbs used as a non-estrogenic treatment for cancer of the prostate, has potent estrogenic activity both in vivo and in vitro. In many cases, however, the mechanisms by which these herbs produce their effect remains to be fully elucidated. Little is known about the agonistic or antagonistic effects of various herbs that are used as herbal medicine on nuclear receptors. In the present study, 24 herbs traditionally used by herbalists for treating a variety of health problems were extracted and tested for their interaction with ERs. 
Here we report that one of the herbs, Rhei rhizoma (rhubarb), has estrogenic activity both in vivo and in vitro. We also demonstrated that the phytochemical lindleyin, a major component of rhubarb extract, is a major contributor to this estrogenic activity and is a novel phytoestrogen.

\section{Materials and Methods}

\section{Materials}

Herb powders were kindly provided by Tsumura \& Co. (Tokyo, Japan). (-)-Epicatechin 3-o-gallate, rhein, sennoside $\mathrm{A}$, and lindleyin were also provided by Tsumura \& Co. Naphthalene was purchased from Nacalai Tesque (Kyoto, Japan). The ER agonist estradiol-17 $\beta$ (E2) was purchased from Nacalai Tesque, and 4-hydroxytamoxifen, the ER antagonist, was purchased from Sigma Chemical Co. (St Louis, MO, USA). Tri-iodothyronine (T3) was purchased from Nacalai Tesque. Troglitazone was provided by Sankyo Pharmaceutical Company (Tokyo, Japan). Daidzein and geninstein were purchased from Wako (Kyoto, Japan). TSA201 cells, clones of human embryonic kidney 293 cells (Margolskee et al. 1993), were used for all transfection experiments.

\section{Preparation of herbal extracts}

Stock solutions of herbal extracts were prepared as follows. Herbal powders $(100 \mathrm{mg})$ were suspended in $10 \mathrm{ml}$ water (dilution 1:100, w/v), sonicated for $1 \mathrm{~min}$, and centrifuged at 3500 r.p.m. for $15 \mathrm{~min}$. The supernatants were filtered through a $0.45 \mu \mathrm{m}$ filter (DISMIC25CS; Tokyo Roshii, Tokyo, Japan).

The herbs used in this study were numbered as follows: 1 Cnidii rhizoma, 2 Forsythiae fructus, 3 Atractylodis rhizoma, 4 Ginseng radix, 5 Paeoniae radix, 6 Cinnamoni cortex, 7 Moutan cortex, 8 Sinomeni caulis et rhizoma, 9 Zingiberis rhizoma, 10 Schizonepetae spica, 11 Atractylodis lanceae rhizoma, 12 Hoelen, 13 Schisandrae fructus, 14 Pinelliae tuber, 15 Gardeniae fructus, 16 Zizyphi fructus, 17 Bupleuri radix, 18 Platycodi radix, 19 Alismatis rhizoma, 20 Angelicae radix, 21 Magnoliae flos, 22 Rhei rhizoma (rhubarb), 23 Polypous, and 24 Ophiopgonis tuber.

\section{Plasmids}

pGAL-ER $\alpha$, pGAL-ER $\beta$, pGAL-TR $\alpha$, and pGAL$\operatorname{PPAR} \gamma$ were constructed as follows: the ligand-binding domain of human ER $\alpha$ (amino acid 282-595), ER $\beta$ (amino acids 240-530), thyroid hormone receptor (TR) $\alpha$ (amino acids 120-410), and peroxisome proliferatoractivated receptor- $\gamma$ (PPAR $\gamma$ ) (amino acids 204-506) were amplified by polymerase chain reaction (PCR) and subcloned into a pM vector (Clontech, Palo Alto, CA, USA) which carries the DNA-binding domain of GAL4
(GALDBD) in frame to generate GALDBD, a chimeric protein. Expression vector for full-length ER $\alpha$ (pCMXER $\alpha$, called pER $\alpha$ full) has been described elsewhere (Chien et al. 1999). Expression vector for fulllength human $\operatorname{ER} \beta$ (pER $\beta$ full) was generated by PCR and subcloned into pcDNA3.1 (Invitrogen). PG5-luc, which has a firefly luciferase reporter gene under the control of five tandem repeats of the GAL4 recognition site, and pRL-TK, which harbors the Renilla luciferase reporter gene driven by thymidine kinase promoter, were obtained from Promega (Madison, WI, USA). The reporter plasmid ERE2-tk109-luc was described previously (Gehm et al. 1997).

\section{Transfection}

TSA201 cells, a clone of human embryonic kidney 293 cells (Margolskee et al. 1993), were maintained in phenol red-free Dulbecco's modified Eagle's medium (Nikken Biomedical Laboratory, Kyoto, Japan) containing 10\% charcoal-treated fetal bovine serum (ICN Biochemical Inc., Costa Mesa, CA, USA), and 1\% penicillin/ streptomycin (Gibco-BRL, Grand Island, NY, USA) at $37^{\circ} \mathrm{C}$ in $5 \% \mathrm{CO}_{2}$. One day before transfection, cells were seeded at approximately 0.5 to $1 \times 10^{6} /$ well in 12 -well plates, and transfection was performed using the calcium phosphate co-precipitation method (Nagaya et al. 1992). The amounts of transfected plasmids were as follows: $50 \mathrm{ng}$ for pGAL-derived plasmids or expression vectors for fulllength ERs (pER $\alpha$ full and pER $\beta$ full), $100 \mathrm{ng}$ for pG5-luc or ERE2-tk109-Luc, and $5 \mathrm{ng}$ for pRL-TK plasmids per well. Herbal extracts or various chemicals were added to the medium $8 \mathrm{~h}$ after transfection. Forty-eight hours after transfection, cells were harvested and assayed for luciferase activity using the Picagene kit (Promega) following the manufacturer's protocol. The luciferase activity was detected using a Plate Lumino luminometer (Stratec Biomedical Systems, Birkenfeld, Germany). In all experiments, both firefly and Renilla luciferase activities were measured to monitor the transfection efficiency and cytotoxicity of the added materials.

\section{ER competitor assay}

A fluorescence polarization assay was performed to examine the in vitro binding of lindleyin to ER $\alpha$. ER $\alpha$ was added to a fluorescent estrogen (Fluormone ${ }^{\mathrm{TM}}$ ES2, PanVera, Madison, WI, USA) ligand to form an ES2/ER $\alpha$ complex with high fluorescence polarization. The complex was then added to various concentrations of either bisphenol A or lindleyin. These experiments were performed using an ER $\alpha$ competitor assay kit (PanVera) and performed according to the manufacturer's protocol. Polarization values were read using a Becon 2000 fluorescence polarization instrument (PanVera) at $485 \mathrm{~nm}$ excitation and $530 \mathrm{~nm}$ emission. Each data point in the 


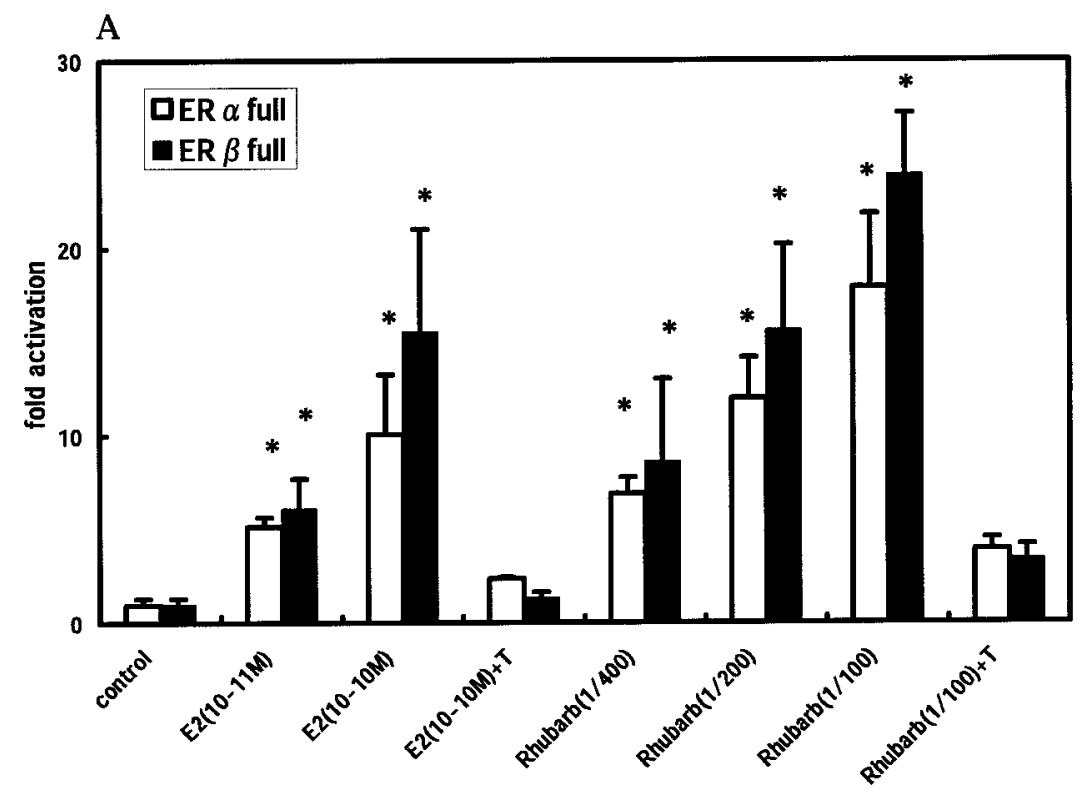

B

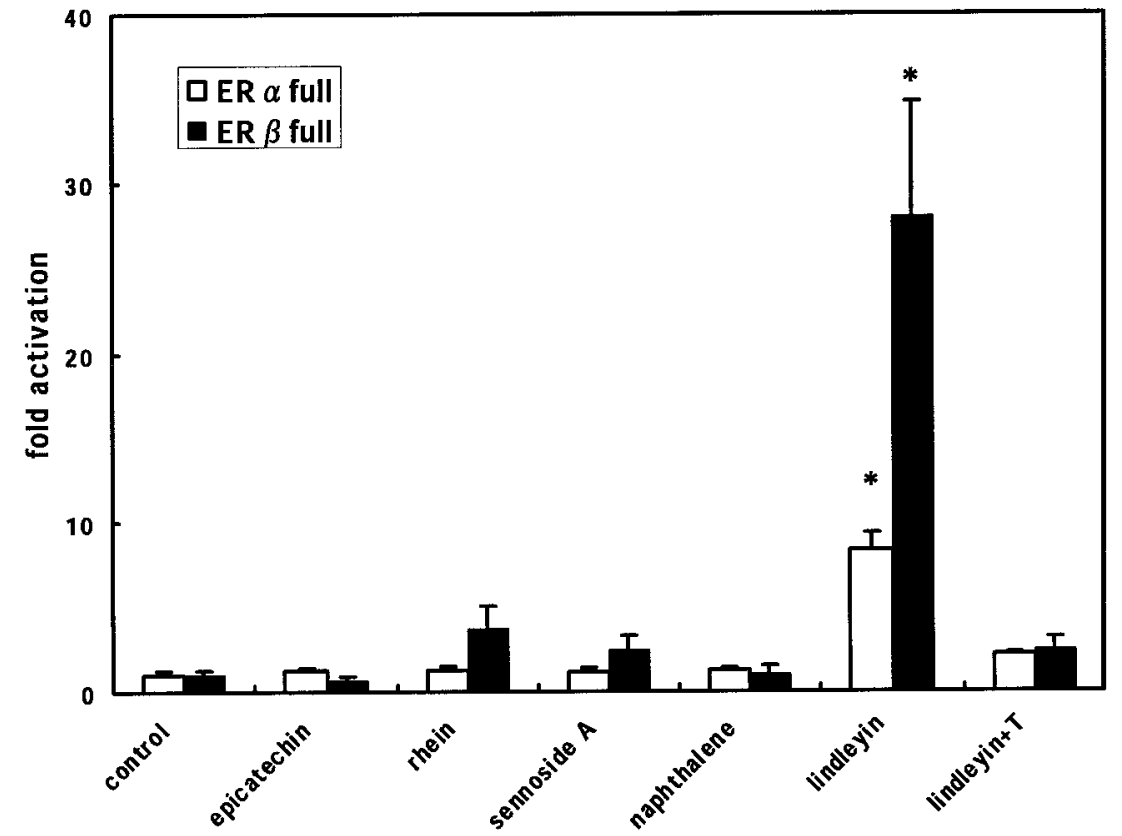

Figure 1 Transcriptional activity of rhubarb extract and five major components of rhubarb for ER $\alpha$ and ER $\beta$. TSA201 cells were transfected with 100 ng EREtkLuc, 5 ng pRL-TK plasmid, and $50 \mathrm{ng}$ pERafull (ER $\alpha$ full) or pER $\beta$ full (ER $\beta$ full). (A) The cells were harvested $48 \mathrm{~h}$ after transfection in the presence of rhubarb extract $(1 / 400,1 / 200$, and $1 / 100$ dilution of the stock solution) or E2 $\left(10^{-11}\right.$ and $\left.10^{-10} \mathrm{~mol} / \mathrm{l}\right)$. (B) The cells were harvested $48 \mathrm{~h}$ after transfection in the presence of five components of rhubarb. The components of rhubarb used in this study were as follows: $(-)$ - epicatechin 3-o-gallate (epicatechin), $10^{-6} \mathrm{~mol} / \mathrm{l}$; rhein, $10^{-6} \mathrm{~mol} / \mathrm{l}$; sennoside $\mathrm{A}, 10^{-6} \mathrm{~mol} / \mathrm{l}$; naphthalene, $10^{-6} \mathrm{~mol} / \mathrm{l}$; lindleyin, $10^{-6} \mathrm{~mol} / \mathrm{l}$. The addition of $10^{-6} \mathrm{~mol} / \mathrm{l}$ 4-hydroxytamoxifen is indicated as $+\mathrm{T}$. Results are indicated as fold activation. The data represented are the means \pm S.D. $(n=4)$. ${ }^{*} P<0 \cdot 001$ vs controls. 


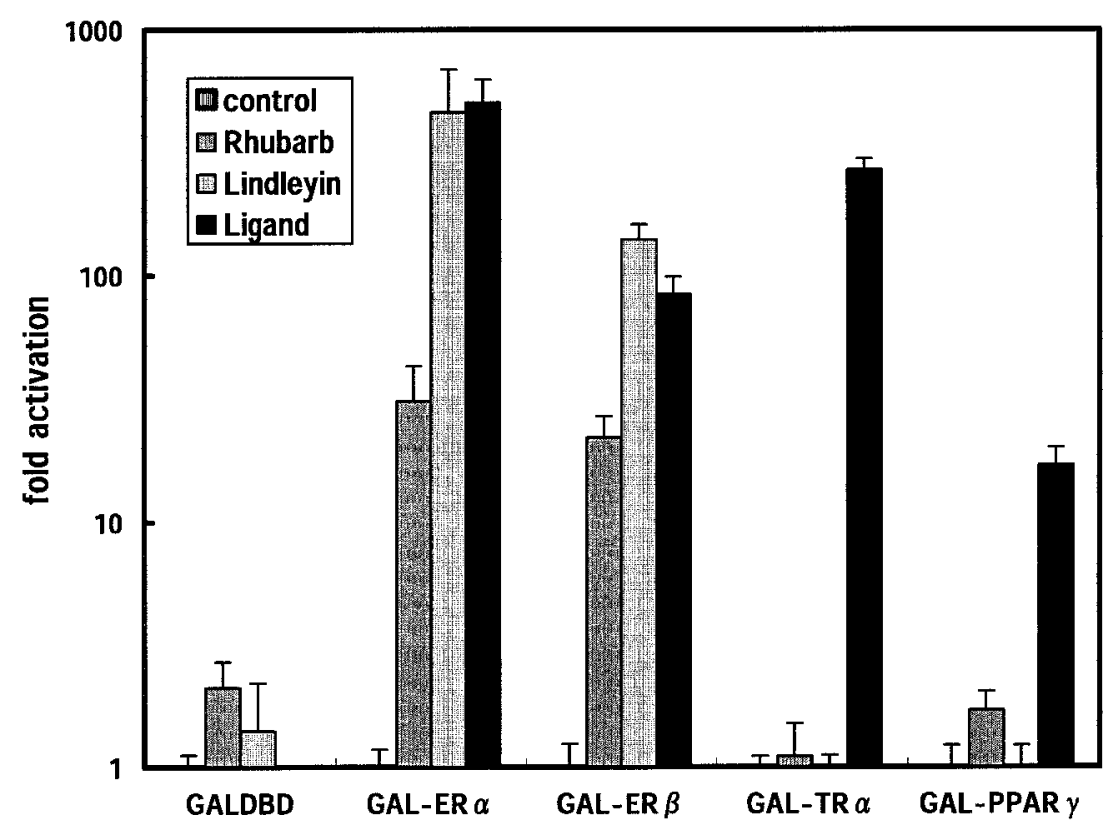

Figure 2 The effects of rhubarb extract, lindleyin and ligands on ER $\alpha_{-}, E R \beta-$, TR $\alpha_{--}$, and PPAR $\gamma$-induced reporter gene expression. TSA201 cells were transfected with $100 \mathrm{ng}$ pG5-luc, $5 \mathrm{ng}$ pRL-TK, and $50 \mathrm{ng}$ pM, pGAL-ER $\alpha$ (GAL-ER $\alpha$ ), pGAL-ER $\beta$ (GAL-ER $\beta$ ), pGAL-TR $\alpha$ (GAL-TR $\alpha)$, or pGAL-PPAR $\gamma(G A L-P P A R \gamma)$. The cells were harvested $48 \mathrm{~h}$ after transfection in the presence of extract $(1 / 100$ dilution $(\mathrm{w} / \mathrm{v})$ of stock solution), lindleyin $\left(10^{-6} \mathrm{~mol} / \mathrm{l}\right)$ and E2 $\left(10^{-10} \mathrm{~mol} / \mathrm{l}\right)$ for ERs, T3 $\left(10^{-6} \mathrm{~mol} / \mathrm{l}\right)$ for TR, and troglitazone $\left(10^{-6} \mathrm{~mol} / \mathrm{l}\right)$ for PPAR $\gamma$. Results are indicated as fold activation compared with the pM-transfected cells. The data represented are the means \pm S.D. $(n=4)$.

polarization assay was run in triplicate, and the reported data are the means \pm S.D. of three experiments.

\section{Medaka vitellogenin assay}

Male Japanese medaka (Oryzias latipes, orange-red type) were purchased from a dealer. They were kept in indoor tanks and fed TetraMin flakes (TetraWerke, Melle, Germany). After a week maintained in fresh water, they were divided into three groups: exposure to E2 (3 p.p.b.), exposure to rhubarb (1/400 dilution of rhubarb stock solution), and controls. After $48 \mathrm{~h}$, their blood was collected for vitellogenin assay. Vitellogenin levels were measured using an EnBio vitellogenin medaka enzyme-linked immunosorbent assay (ELISA) System (Amersham Pharmacia Biotech, Arlington Heights, IL, USA) according to the manufacturer's protocol.

\section{Results}

The effect of rhubarb and lindleyin on ERa- and ER $\beta$-transfected cells

Of the 24 herbs examined in this study, only rhubarb extract showed significant reporter gene activation in
ER-transfected TSA201 cells (data not shown). The effect of rhubarb extract was dose dependent, and the addition of a $1 / 200$ dilution of stock solution to the culture medium was equivalent to approximately $10^{-10} \mathrm{~mol} / 1 \mathrm{E} 2$. The rhubarb-induced reporter gene activation was blocked by 4-hydroxytamoxifen (Fig. 1A). To determine which components of rhubarb extract contribute to its estrogenic activity, we studied the effects of five known major components of rhubarb on reporter gene expression. (-)-Epicatechin 3-o-gallate, rhein, sennoside A, and naphthalene had no effect on reporter gene expression in pER $\alpha$ full- and $\mathrm{pER} \beta$ full-transfected cells. In contrast, the addition of $10^{-6} \mathrm{~mol} / 1$ lindleyin markedly increased the reporter gene transcription in both pERafull- and $\mathrm{pER} \beta$ full-transfected cells (Fig. 1B). Moreover, lindleyininduced reporter gene transcription in pER afull- and pER $\beta$ full-transfected cells was completely reversed by 4-hydroxytamoxifen. To demonstrate the specificity of the effects of rhubarb extract and lindleyin on ER-mediated reporter gene activation, we studied the effects of rhubarb and lindleyin on pGAL-TR $\alpha$ and pGAL-PPAR $\gamma$. As shown in Fig. 2, neither rhubarb extract nor lindleyin had an effect on TR $\alpha$ - or PPAR $\gamma$-mediated reporter gene expression, indicating that the interaction of rhubarb extract and lindleyin on ERs are specific. Figure 3 


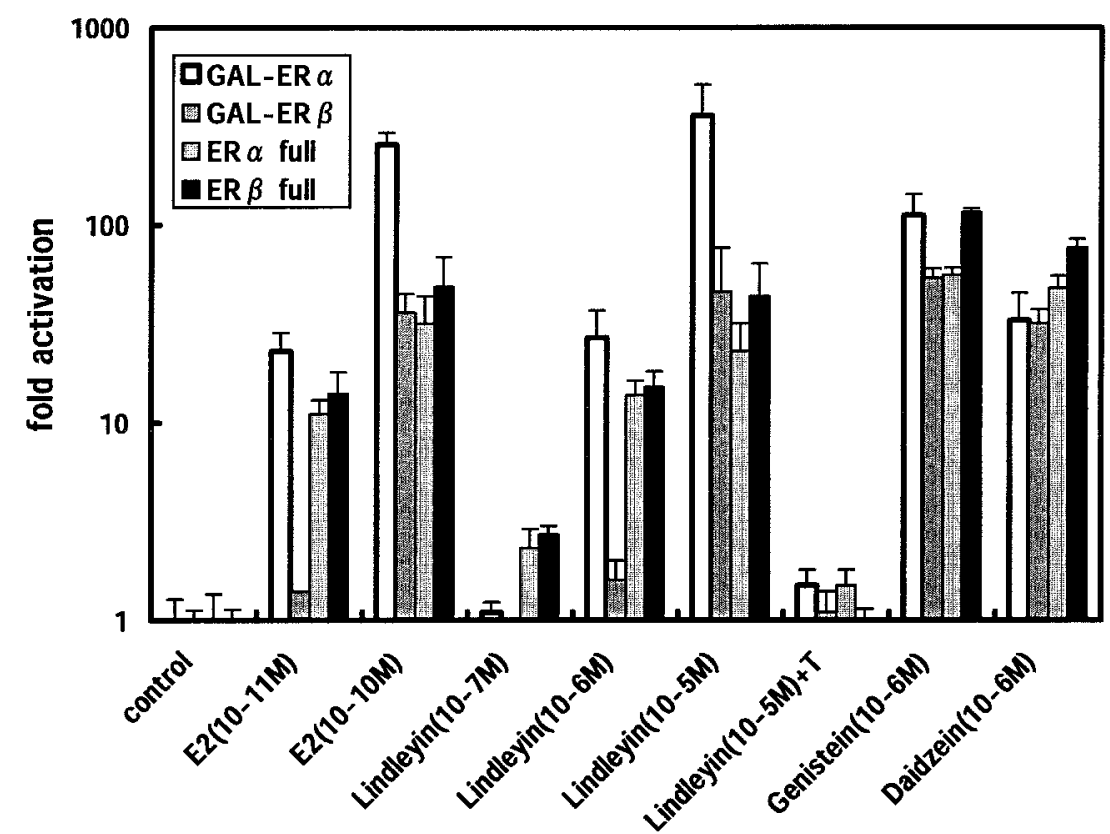

Figure 3 The effect of E2, lindleyin, genistein, daidzein and 4-hydroxytamoxifen on GAL-ER $\alpha-$, GAL-ERß-, ERafull-, and ERßfull-mediated reporter gene expression. TSA201 cells were transfected with $100 \mathrm{ng}$ pG5-luc or EREtk-luc, $5 \mathrm{ng}$ pRL-TK plasmid, and 50 ng

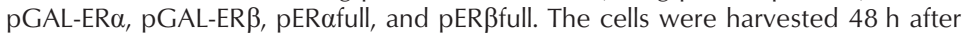
transfection in the presence of E2 $\left(10^{-11} \mathrm{~mol} / \mathrm{l}\right.$ and $\left.10^{-10} \mathrm{~mol} / \mathrm{l}\right)$, lindleyin $\left(10^{-7}, 10^{-6}\right.$, and $\left.10^{-5} \mathrm{~mol} / \mathrm{l}\right)$, genistein $\left(10^{-6} \mathrm{~mol} / \mathrm{l}\right)$, and daizein $\left(10^{-6} \mathrm{~mol} / \mathrm{l}\right)$. Addition of $10^{-6} \mathrm{~mol} / \mathrm{l}$ 4-hydroxytamoxifen is indicated as $+\mathrm{T}$. Results are indicated as fold activation. The data represented are the means \pm S.D. $(n=4)$.

shows the effects of lindleyin, genistein, and daidzein on GAL4-ERs and full-length ERs on reporter gene expression. Lindleyin at $10^{-5} \mathrm{~mol} / \mathrm{l}$ activated GAL4-ER and full-length-mediated reporter gene expression. The potency of $10^{-5} \mathrm{~mol} / 1$ lindleyin is equivalent to approximately $10^{-6} \mathrm{~mol} / \mathrm{l}$ genistein and daidzein.

\section{Lindleyin binds to ERa in vitro}

A fluorescence polarization assay was performed to confirm the in vitro binding of lindleyin to ER $\alpha$. Lindleyin $\left(10^{6} \mathrm{nmol} / \mathrm{l}\right)$ replaced approximately $40 \%$ of the labeled estrogen (Fig. 4). The $\mathrm{IC}_{50}$ values of $\mathrm{E} 2$ and bisphenol $\mathrm{A}$ were $13.9 \mathrm{nmol} / 1$ and $45 \mu \mathrm{mol} / 1$ respectively. The $\mathrm{IC}_{50}$ of lindleyin was calculated to be $225 \cdot 2$ to $435 \cdot 8 \mu \mathrm{mol} / 1$, which is approximately $0.005 \%$ that of E2 and $14 \%$ that of bisphenol A.

\section{Exposure to rhubarb extract increased serum vitellogenin levels} in male medaka

The in vivo effect of rhubarb was studied using a vitellogenin assay in Japanese medaka. Vitellogenin is a yolk protein, which is scarcely present in male medaka, and is markedly induced by environmental estrogenic com- pounds (Gronen et al. 1999, Shioda \& Wakabayashi 2000). Exposure to 3 p.p.b. of E2 markedly increased serum vitellogenin levels. Exposure to a 1/400 dilution of stock solution of rhubarb markedly increased serum vitellogenin

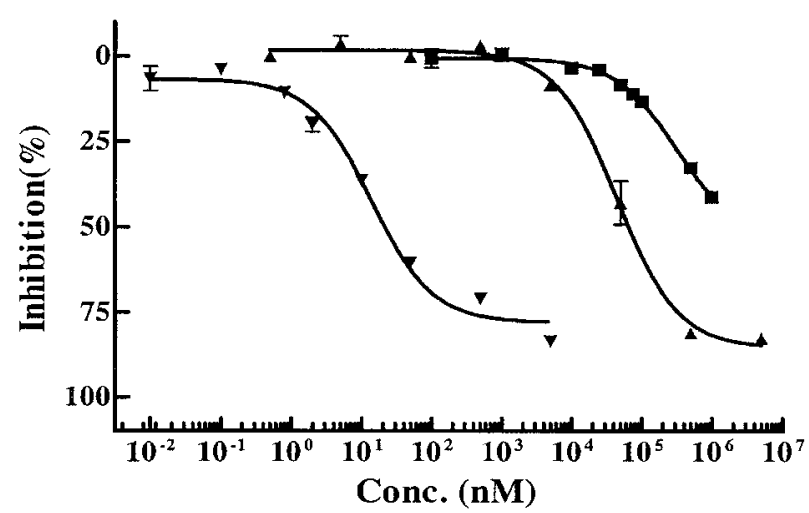

Figure 4 Competition binding curves of E2, bisphenol A, and lindleyin against a human recombinant ER $\alpha /$ fluorescent ligand complex. Increasing concentrations of competitors (E2 $(\boldsymbol{\nabla})$, bisphenol A ( $\mathbf{\Delta})$, and lindleyin $(\boldsymbol{\square}))$ were incubated with human $\mathrm{ER} \alpha$ and fluorescent estrogen for $60 \mathrm{~min}$ at room temperature followed by measurement of fluorescence polarization. Data points and error bars represent the means \pm S.D. $(n=3)$. 


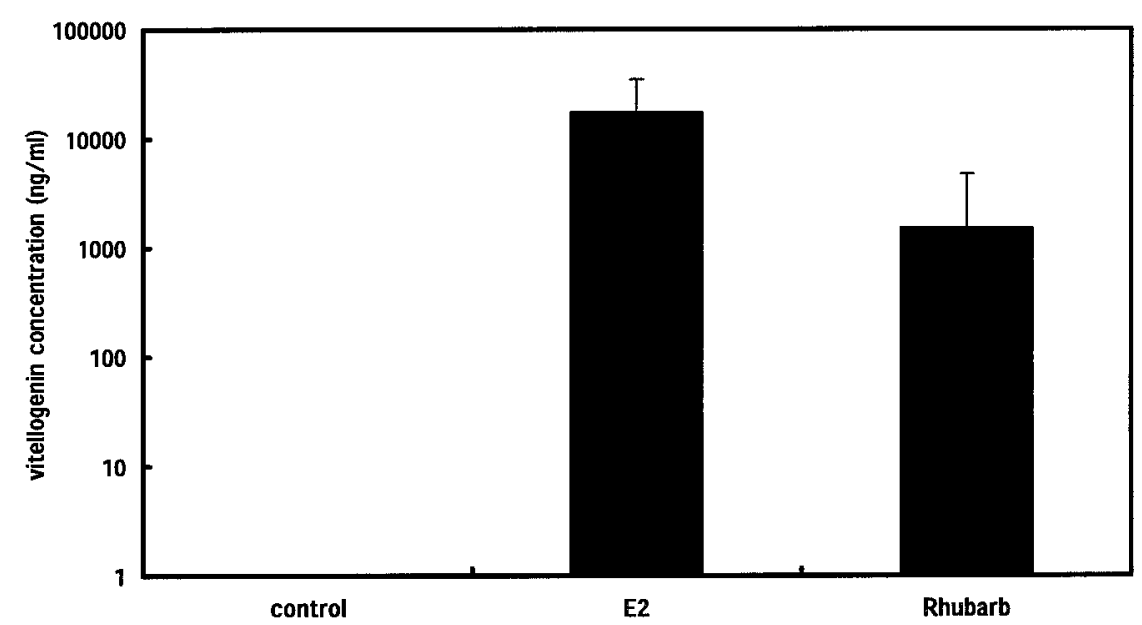

Figure 5 The effect of E2 and rhubarb extract on serum vitellogenin levels in male medaka. Male medaka were divided into three groups, control $(n=8)$, exposure to E2 $(3 \mathrm{ppb})(n=5)$, and exposure to rhubarb extract ( $1 / 400$ dilution of stock solution) $(n=8)$. After $48 \mathrm{~h}$ of exposure, serum vitellogenin levels were assayed using an ELISA as described in the Materials and Methods. The data represented are the means \pm S.D.

levels, whereas none of the control medaka had increased serum vitellogenin concentrations (Fig. 5).

\section{Discussion}

Herbal medicine is used as an alternative medicine in most countries. The precise molecular mechanisms of the various biological effects, however, are not known. Some herbal components such as PC-SPES, a blend of eight Chinese medical herbs, have estrogenic activity both in vitro and in vivo, and improve the tumor marker level in prostate cancer patients (DiPaola et al. 1998). Some plants have estrogenic compounds known as phytoestrogens or estrogenic flavonoids. The results of the present study demonstrated that rhubarb extract has profound estrogenic effects via both $\mathrm{ER} \alpha$ and $\mathrm{ER} \beta$. As the major components of rhubarb contain no known phytoestrogens, this herb must contain some unknown phytoestrogens. Rhubarb is traditionally used as an antiphlogistic, cathartic, antipyretic, anticoagulant, and homeostatic prescription in Chinese medicine (Kosuge \& Ishida 1985). A 1/200 dilution of the stock solution of rhubarb has estrogenic activity equivalent to $10^{-10} \mathrm{~mol} / 1 \mathrm{E} 2$ in ER $\alpha$-transfected cells. Of the five major components of rhubarb, only lindleyin stimulates reporter gene expression, suggesting that lindleyin might be the major contributor to the ER-mediated estrogenic activity of rhubarb. The fact that the estrogenic activity of rhubarb and lindleyin was completely reversed by adding 4-hydroxytamoxifen indicates that these effects were due to interactions with the ERs. Previous reports have demonstrated greater binding to and activation of ER $\beta$ vs ER $\alpha$ by phytoestrogens
(Kuiper et al. 1997, 1998, Barkhem et al. 1998, McInerney et al. 1998, An et al. 2001). At the concentrations of genistein and daidzein that were used in these previous reports, stronger transcriptional activity was observed on ER $\beta$ than ER $\alpha$ in our reporter gene assay system (data not shown). Unlike these known phytoestrogens, lindleyin interacts equally with $\operatorname{ER} \alpha$ and $\operatorname{ER} \beta$ when the full-length plasmid is used. Both rhubarb extract and lindleyin, however, had no effect on other nuclear receptors such as $\mathrm{TR} \alpha$ or PPAR $\gamma$, suggesting that the ER interactions are specific. In our reporter gene assay, the estrogenic activity of lindleyin is approximately tenfold less effective at the same concentration of genistein or daidzein.

To confirm that the estrogenic effects of lindleyin occurred through direct receptor interaction, the binding of lindleyin to ER $\alpha$ was analyzed using a fluorescent polarization assay. The binding affinity of lindleyin to ER $\alpha$ was approximately $0 \cdot 005 \%$ that of E2 and $14 \%$ that of bisphenol. The binding affinities of genistein and daidzein to ER $\alpha$ were reported to be $4 \%$ and $0 \cdot 1 \%$ in solid-phase competition experiments, and $0 \cdot 7 \%$ and $0.2 \%$ in solubilized receptor competition experiments (Kuiper et al. 1998). The discrepancy between the low binding affinity to the receptor and strong transactivation in vivo might be explained by the fact that lindleyin can induce, at least partially, conformational changes involved in the formation of a transcriptionally competent activation function in the ligand-binding domain (Brzozowski et al. 1997).

Because of the limited amount of lindleyin available, we studied the in vivo effect using rhubarb extract in a medaka vitellogenin assay system. Vitellogenin levels in medaka exposed to rhubarb extract were remarkably higher than in controls, showing that rhubarb contains some estrogenic 
<smiles>CC12CCC3c4ccc(O)cc4CCC3C1CC[C@@H]2O</smiles>

\section{$17 \beta$-Estradiol}<smiles>O=c1c(-c2ccc(O)cc2)coc2cc(O)cc(O)c12</smiles>

\section{Genistein}

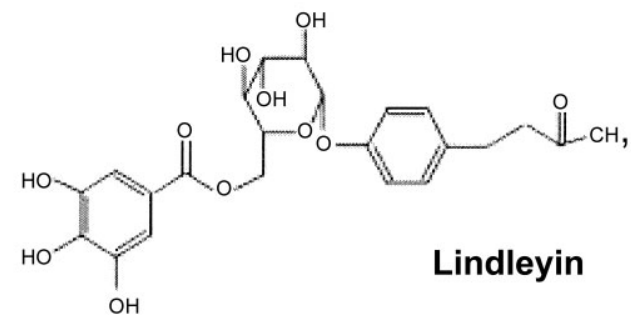

Figure 6 Structures of lindleyin, genistein, and estradiol.

compounds that affect vitellogenin synthesis through ERs expressed in medaka liver.

Lindleyin is a glucoside obtained from Aeonium lindrleyi (Darias et al. 1978), a crassulacea endemic to the Canary Islands. Its formula (4-(4'-hydroxyphenyl)-2-butanone$4^{\prime}-O-\beta-\mathrm{D}-\left(6^{\prime \prime}-O\right.$-gallyl $)$ glucopyranoside $)$ is shown in Fig. 6. Like other estrogenic compounds, it has a phenolic backbone. We therefore conclude that lindleyin is a novel phytoestrogen. The potential biological impact of environmental and dietary estrogens on human health has generated considerable interest (Cotton 1994, Safe 1995, Feldman 1997). These agents include phytoestrogens as well as a variety of synthetic compounds. Pharmacological information about lindleyin is limited and there are no reports on the measurement of plasma lindleyin levels in humans. Daidzein and genistein are well-characterized phytoestrogens and their plasma concentrations in Japanease and Finnish populations have been reported (Adlercreutz et al. 1993). In vivo experiments on lindleyin are needed to address its pharmacological effects on humans. An estrogenic hydroxystilbene was recently reported to occur naturally in wood (Mellanen et al. 1996), and hops contain the potential phytoestrogen, 8-prenylnaringenin (Milligan et al. 1999). Gehm et al. (1998) reported that the phytochemical, resveratrol, present in grapes and wine, is a phytoestrogen which exhibits variable degrees of ER agonism. Bowers et al. (2000) reported that resveratrol acts as a mixed agonist/ antagonist for ER $\alpha$ and ER $\beta$. Recently, Burow et al.
(2001) reported that phytochemical glyceollins mediate antihormonal effects through ER $\alpha$ and $\operatorname{ER} \beta$.

The finding that lindleyin is estrogenic not only expands the spectrum of known dietary phytoestrogens but is also useful as a novel tool for examining the action of estrogen. There are no reports on the long-term effect of lindleyin or rhubarb on human health; however, it has a potential benefit as a novel selective ER modulator (Cosman \& Lindsay 1999) for the postmenopausal syndrome, atherosclerosis, or osteoporosis. Further studies, however, are required to assess the physiological significance of lindleyin in humans, and a more complete understanding of its estrogenic action is needed to understand its role as a dietary substance.

\section{Acknowledgements}

We thank Tsumura \& Co. for providing the herbal powders and chemical components of rhubarb. We also thank Takara Shuzo Co. Ltd for performing the fluorescence polarization assay. This work was supported in part by a grant from the Ministry of Health, Labor, and Welfare, Suzuken Memorial Foundation and the Foundation for the Growth of Science in Japan.

\section{References}

Adlercreutz H 1995 Phytoestrogens: epidemiology and a possible role in cancer protection. Environmental Health Perspectives 103 103-112.

Adlercreutz H, Markkanen H \& Watanabe S 1993 Plasma concentrations of phyto-oestrogens in Japanese men. Lancet 342 1209-1210.

An J, Tzagarakis-Foster C, Scharschmidt TC, Lomri N \& Leitman DC 2001 Estrogen receptor beta-selective transcriptional activity and recruitment of coregulators by phytoestrogens. Journal of Biological Chemistry 276 17808-17814.

Barkhem T, Carlsson B, Nilsson Y, Enmark E, Gustafsson J \& Nilsson S 1998 Differential response of estrogen receptor alpha and estrogen receptor beta to partial estrogen agonists/antagonists. Molecular Pharmacolology 54 105-112.

Bennetts HW, Underwood EJ \& Shier FL 1946 A specific breeding problem of sheep on subterranean clover pastures in Western Australia. Australian Veterinary Journal 22 2-12.

Bingham SA, Atkinson C, Liggins J, Bluck L \& Coward A 1998 Phyto-oestrogens: where are we now? British Journal of Nutrition 79 393-406.

Bowers JL, Tyulmenkov VV, Jernigan SC \& Klinge CM 2000 Resveratrol acts as a mixed agonist/antagonist for estrogen receptors alpha and beta. Endocrinology 141 3657-3667.

Brzozowski AM, Pike AC, Dauter Z, Hubbard RE, Bonn T, Engstrom O, Ohman L, Greene GL, Gustafsson JA \& Carlquist M 1997 Molecular basis of agonism and antagonism in the oestrogen receptor. Nature 389 753-758.

Burow ME, Boue SM, Collins-Burow BM, Melnik LI, Duong BN, Carter-Wientjes CH, Li S, Wiese TE, Cleveland TE \& McLachlan JA 2001 Phytochemical glyceollins, isolated from soy, mediate antihormonal effects through estrogen receptor alpha and beta. Journal of Clinical Endocrinology and Metabolism 86 1750-1758.

Chien PY, Ito M, Park Y, Tagami T, Gehm BD \& Jameson JL 1999 A fusion protein of the estrogen receptor (ER) and nuclear receptor 
corepressor (NCoR) strongly inhibits estrogen-dependent responses in breast cancer cells. Molecular Endocrinology 13 2122-2136.

Cline JM \& Hughes CL Jr 1998 Phytochemicals for the prevention of breast and endometrial cancer. Cancer Treatment and Research 94 107-134.

Cosman F \& Lindsay R 1999 Selective estrogen receptor modulators: clinical spectrum. Endocrine Reviews 20 418-434.

Cott JM 1997 In vitro receptor binding and enzyme inhibition by Hypericum perforatum extract. Pharmacopsychiatry 30 108-112.

Cotton P 1994 Environmental estrogenic agents area of concern. Journal of the American Medical Association 414416.

Darias V, Gonzales AG, Boada JN, Feria M \& Martorell F 1978 Pharmacological study of lindleyin. Farmaco 33 460-467.

Delos S, Carsol JL, Ghazarossian E, Raynaud JP \& Martin PM 1995 Testosterone metabolism in primary cultures of human prostate epithelial cells and fibroblasts. Journal of Steroid Biochemistry and Molecular Biology 55 375-383.

DiPaola RS, Zhang H, Lambert GH, Meeker R, Licitra E, Rafi MM, Zhu BT, Spaulding H, Goodin S, Toledano MB, Hait WN \& Gallo MA 1998 Clinical and biologic activity of an estrogenic herbal combination (PC-SPES) in prostate cancer. New England Journal of Medicine 339 785-791.

Feldman D 1997 Estrogens from plastic - are we being exposed? Endocrinology 138 1777-1779.

Fotsis T, Pepper M, Adlercreutz H, Fleischmann G, Hase T, Montesano R \& Schweigerer L 1993 Genistein, a dietary-derived inhibitor of in vitro angiogenesis. PNAS 90 2690-2694.

Gehm BD, McAndrews JM, Chien PY \& Jameson JL 1997 Resveratrol, a polyphenolic compound found in grapes and wine, is an agonist for the estrogen receptor. PNAS 94 14138-14143.

Gronen S, Denslow N, Manning S, Barnes S, Barnes D \& Brouwer M 1999 Serum vitellogenin levels and reproductive impairment of male Japanese medaka (Oryzias latipes) exposed to

4-tert-octylphenol. Environmental Health Perspectives 107 385-390.

Hughes C 1996 Are the differences between estradiol and other estrogens merely semantical? Journal of Clinical Endocrinology and Metabolism 812405.

Humfrey CD 1998 Phytoestrogens and human health effects: weighing up the current evidence. Journal of Natural Toxins 6 $51-59$.

Jordan VC, Mittal S, Gosden B, Koch R \& Lieberman ME 1985 Structure-activity relationships of estrogens. Environmental Health Perspectives 61 97-110.

de Kleijn MJ, van der Schouw YT, Wilson PW, Adlercreutz H, Mazur W, Grobbee DE \& Jacques PF 2001 Intake of dietary phytoestrogens is low in postmenopausal women in the United States: the Framingham study (1-4). Journal of Nutrition 131 1826-1832.

Kosuge T \& Ishida H 1985 Studies on active substances in the herbs used for oketsu ('stagnant blood') in Chinese medicine. IV On the anticoagulative principle in Rhei rhizoma. Chemical and Pharmaceutical Bulletin 33 1503-1506.

Kuiper GG, Carlsson B, Grandien K, Enmark E, Haggblad J, Nilsson S \& Gustafsson JA 1997 Comparison of the ligand binding specificity and transcript tissue distribution of estrogen receptors alpha and beta. Endocrinology 138 863-870.
Kuiper GG, Lemmen JG, Carlsson B, Corton JC, Safe SH, van der Saag PT, van der Burg B \& Gustafsson JA 1998 Interaction of estrogenic chemicals and phytoestrogens with estrogen receptor beta. Endocrinology 139 4252-4263.

McInerney EM, Weis KE, Sun J, Mosselman S \& Katzenellenbogen BS 1998 Transcription activation by the human estrogen receptor subtype beta (ER beta) studied with ER beta and ER alpha receptor chimeras. Endocrinology 139 4513-4522.

Margolskee RF, McHendry-Rinde B \& Horn R 1993 Panning transfected cells for electrophysiological studies. Biotechniques $\mathbf{1 5}$ 906-911.

Martin PM, Horwitz KB, Ryan DS \& McGuire WL 1978 Phytoestrogen interaction with estrogen receptors in human breast cancer cells. Endocrinology 103 1860-1867.

Mellanen P, Petanen T, Lehtimaki J, Makela S, Bylund G, Holmbom B, Mannila E, Oikari A \& Santti R 1996 Wood-derived estrogens: studies in vitro with breast cancer cell lines and in vivo in trout. Toxicology and Applied Pharmacology 136 381-388.

Milligan SR, Kalita JC, Heyerick A, Rong H, De Cooman L \& De Keukeleire D 1999 Identification of a potent phytoestrogen in hops (Humulus lupulus L.) and beer. Journal of Clinical Endocrinology and Metabolism 84 2249-2252.

Murkies AL, Wilcox G \& Davis SR 1998 Clinical review 92: Phytoestrogens. Journal of Clinical Endocrinology and Metabolism $\mathbf{8 3}$ 297-303.

Nagaya T, Madison LD \& Jameson JL 1992 Thyroid hormone receptor mutants that cause resistance to thyroid hormone. Evidence for receptor competition for DNA sequences in target genes. Journal of Biological Chemistry 267 13014-13019.

Price KR \& Fenwick GR 1985 Naturally occurring oestrogens in foods - a review. Food Additives and Contaminants 2 73-106.

Safe SH 1995 Environmental and dietary estrogens and human health: is there a problem? Environmental Health Perspectives 103 346-351.

Schinckel PG 1948 Infertility in ewes grazing subterranean clover pastures. Observations on breeding following transfer to sound country. Australian Veterinary Journal 24 289-294.

Setchell KD \& Cassidy A 1999 Dietary isoflavones: biological effects and relevance to human health. Journal of Nutrition 129 758S-767S.

Setchell KD, Gosselin SJ, Welsh MB, Johnston JO, Balistreri WF, Kramer LW, Dresser BL \& Tarr MJ 1987 Dietary estrogens - a probable cause of infertility and liver disease in captive cheetahs. Gastroenterology 93 225-233.

Shioda T \& Wakabayashi M 2000 Effect of certain chemicals on the reproduction of medaka (Oryzias latipes). Chemosphere 40 239-243.

Shutt DA 1976 The effects of plant oestrogens on animal reproduction. Endeavour 35 110-113.

Tham DM, Gardner CD \& Haskell WL 1998 Clinical review 97: Potential health benefits of dietary phytoestrogens: a review of the clinical, epidemiological, and mechanistic evidence. Journal of Clinical Endocrinology and Metabolism 83 2223-2235.

Received 29 May 2002

Accepted 23 July 2002 